\title{
EXAMINING THE ROLE OF INSTITUTIONS IN STRATEGIC LEADERSHIP STRUCTURES USING CONFIGURATIONAL ANALYSIS
}

\author{
RENE OLIE \\ Rotterdam School of Management \\ Erasmus University Rotterdam \\ The Netherlands \\ REKHA RAO-NICHOLSON \\ Newcastle University London
}

\begin{abstract}
This work explores the national differences in strategic leadership across countries with CEO centrality and TMT interdependence as two dimensions. Using configurations of informal and formal institutions as paths to strategic leadership, the combinations of institutions shaping crossnational variations are examined. Results show that national institutions' influence strategic leadership structures.
\end{abstract}

Keywords: Strategic Leadership, formal and informal national institutions, CEO centrality, TMT interdependence, fsQCA.

\section{INTRODUCTION}

How much and under which conditions do top executives matter in shaping strategic behavior and firm outcomes? This has been a central question in most Strategic Leadership (SL) research. Based on the assumption that the CEO is the most powerful person in the organizational hierarchy, much SL research has focused on the CEO in shaping organizational behavior and outcomes (c.f. Finkelstein, Hambrick \& Cannella, 2009). However, with the growing realization that leadership in large, complex organizations is an activity that involves groups of executives rather individual leaders, researchers have also focused on entire Top Management Teams (TMTs) and their effects on firm behavior and outcomes (cf. Finkelstein \& Hambrick, 1996; Carpenter, Geletkanycz, \& Sanders, 2004). The basic premise of this 'Upper Echelon perspective' (Hambrick \& Mason, 1984) is that a focus on TMT characteristics will yield stronger explanations of organizational behavior and outcomes than focusing on the characteristics of individual CEOs (Hambrick, 2007).

Surprisingly, this debate has paid limited attention to the role of national institutional systems in shaping the roles, structures, and responsibilities of CEOs and executive teams. Despite evidence that leadership profiles, leadership styles, roles, and responsibilities vary across countries due to differences in value orientations (Hofstede, 2001) and differences in national governance systems (Aguilera and Jackson, 2010; Olie et al., 2012), research on the cross-national diversity in strategic leadership has been limited. Two studies are worth mentioning. In a three-country study, Crossland and Hambrick (2007) found that CEOs of US-based firms had a significantly higher effect on company performance than CEOs from Germany and Japan. In a follow-up study including 15 different countries, Crossland and Hambrick (2011) examined how nation-level institutions affect the CEO effect. For this purpose, they examined how formal (e.g., ownership dispersion, legal origin, and employer flexibility) and informal institutions (e.g., power distance, 
uncertainty tolerance, and individualism) define CEO managerial discretion, i.e., the leeway of CEOs to pursue their course of action. Both studies underline the relevance of the national institutional context. These findings have raised questions about under what circumstances and in which macro-environments executives experience the most managerial power and matter most in shaping organizational decisions and outcomes (Crossland and Hambrick, 2007; Hambrick and Finkelstein, 1987).

The current paper builds upon Crossland and Hambrick's research in two different ways. First, whereas both studies exclusively focused on the CEO, we will take the CEO-TMT interface as a starting point. In this regard, we will examine both leadership centrality, the relative power of the CEO vis-à-vis other top executives in the TMT and explore the interdependence among top executives. Both SL characteristics define to which extent CEO or TMT effects are essential for explaining organizational outcomes. Second, we explore the necessary and sufficient causal conditions leading to different degrees of leadership centralization and TMT interdependence across 28 countries.

In doing so, we make the following contributions. First, except a few studies (e.g., Crossland and Hambrick, 2007; 2011), researchers to date have paid scant attention to links between country-level institutions and strategic leadership in firms. Second, by adopting an institutional perspective to study cross-country variations, we add to the emergent stream of research studying the role of institutions and their effects on firm behavior and performance (Peng and Jiang, 2010).

\section{Sample and data collection}

\section{METHODOLOGY}

Previous studies on cross-national business phenomena have most often used data on companies in the following 15 countries: Australia, Austria, Canada, France, Germany, Italy, Japan, the Netherlands, Singapore, South Korea, Spain, Sweden, Switzerland, the United Kingdom, and the United States (e.g. Crossland and Hambrick, 2011; La Porta et al., 1997, Schwarz, 1994). We included 13 new countries to increase the heterogeneity of the sample: Belgium, Brazil, Denmark, Finland, India, Ireland, Luxembourg, Mexico, Norway, Portugal, Romania, Russia and South Africa. For each country, we collected data on the top management teams of the top 20 listed companies originating in that country in the period 2011-2013. We used sales turnover as recorded in 2016 by Thompson One Banker to define the top-20. Companies with 60-69 (Banking and Financial Services) and 93 (Public Finance, Taxation, and Monetary Policy) as two-digit SIC (Standard Industry Codes) were excluded from this sample because the performance of firms in these industries is harder to measure and to compare with companies active in other industries. A wide variety of data sources were used. Data on the informal institutions originate from findings by Hofstede (2001), while indices by Botero et al. (2004), La Porta et al. (1999) and Estevez-Abe et al. (2001) were used to operationalize the formal institutions.

\section{Operationalization of the top management team}

To overcome the lack of a universal definition of the TMT, the following operationalization was used. First, the legally required separation of the supervisory board and the management board in two-tier systems makes the operationalization of the top management team in countries under this system straightforward. Here, the TMT is comprised of the CEO and other management board members. In one-tier systems, the identification of which executives are part of the TMT is less straightforward. We considered the CEO and executive directors on the Board of Directors and 
potential other senior managers who are listed in the annual report as persons with executive responsibilities as members of TMTs in countries with one tier systems.

\section{Leadership centrality}

To measure leadership centrality, two indices were created, representing the formal and informal power of the CEO: CEO dominance and CEO status.

CEO dominance. Earlier studies (Lambert et al., 1993; Hill and Phan, 1991) have shown that the CEO's presence in the Board of Directors, and potential CEO duality, can serve as a proxy for CEO power (Finkelstein and D'Aveni, 1994; Zajac and Westphal, 1996).

CEO status Following Wade et al. (2006)'s notion that large pay disparities between the CEO and other TMT members symbolize CEO status and prestige, this study uses individual-level compensation differentials between the CEO and other TMT members as a proxy for CEO status.

\section{TMT interdependence}

To measure team interdependence, we followed Hambrick et al. (2015) in using two structural properties of the TMT: horizontal and vertical interdependence. Horizontal interdependence reflects the interlinkages among peers while vertical interdependence reflects what extent TMT members are hierarchical peers (Hambrick et al., 2015).

\section{Informal institutions: individualism, power distance, and uncertainty tolerance}

Hofstede's scores (2001) for the three informal institutions individualism, power distance, and uncertainty tolerance were used to operationalize these variables. Following Crossland and Hambrick (2011), uncertainty tolerance was operationalized by using the reverse of the uncertainty avoidance scores.

Formal institutions: legal origin, employer flexibility, and ownership dispersion Legal origin. We used Botero et al.'s (2004) binary index to distinguish between common-law (coded as 1) and civil-law countries (coded as 0 ).

Employer flexibility. Similar to Crossland and Hambrick (2011) we operationalize employer flexibility based on indices by Estevez-Abe et al. (2001) and Botero et al. (2004).

Ownership dispersion. We used La Porta et al.'s (1999) findings on ownership structures to measure ownership dispersion in a country.

\section{Analytical method}

A central aim of this study is to identify combinations of formal and informal institutions as causes for a certain level of leadership centrality and TMT interdependence in different countries. To test how the informal and formal institutions are potentially interrelated a fuzzy set Qualitative Comparative Analysis (fsQCA) was performed. This statistical method conceptualizes cases as different kinds of attribute configurations (Greckhamer 2016; Fiss, 2007). An important difference between conventional data analysis and fsQCA is the way of explaining effects (Leischnig et al., 2014). While conventional linear methods analyze the potential effects that one (or more) variable has on a dependent variable, fsQCA has the potential to analyze how combinations of independent variables are related to any outcome (Fiss, 2007), the so-called 'causes-to-effects approach' (Mahoney and Goertz, 2006).

\section{DISCUSSION AND CONCLUSION}


This study aimed at creating a better understanding of cross-national variations in leadership structures and the role of formal and informal institutions in explaining these variations. We argued that leadership centrality and team interdependence, two important characteristics of SL configurations, tend to vary across countries. Based on the data discussed above, we found that companies from different countries in our sample show significant variation in these two characteristics. More importantly, further analyses show that a substantial part of this variation is attributable to between-country differences rather than to firm or industry-level variables. Interestingly, the US, the country in which most SL research has taken place (Olie et al., 2012), has the highest scores on two of the four measures: formal CEO power and vertical team interdependence. This suggests that research findings on US firms cannot be fully generalized to other country settings.

Also, we explored to what extent three formal and three informal institutions explain the two SL characteristics. We assumed that constellations of institutions rather than individual institutions explain SL configurations. Overall, the results provide support for the notion that there are several possible paths to leadership centrality and TMT interdependence. Another conclusion is that both configurations consisting of both formal and informal institutions seem to explain SL configurations. Consistent with Crossland and Hambrick's (2011) suggestion we find that combinations of formal and informal institutions influence strategic leadership patterns. In other words, leadership centralization, for example, is never the result of formal institutions such as legal regulations and governance models alone but always the result of an interplay of formal rules and regulations and informal customs, values, and norms.

\section{Conclusion}

The focus of this study is to gain insight into differences in national institutional contexts and the effects thereof on strategic leadership structures. Results reveal that the conjunction of formal and informal institutional attributes leads to leadership centrality and TMT interdependence and interdependencies between institutions exist. 


\section{REFERENCES}

Aguilera, R.V., and G. Jackson. 2010. "Comparative and International Corporate Governance." Academy of Management Annals 4 (1): 485-556.

Botero J.C., S. Djankov, R. La Porta, F. Lopez-de-Silanes and A. Shleifer. (2004). The regulation of labor. Quarterly Journal of Economics 119: 1339-1382.

Carpenter, M.A, M.A. Geletkanycz; and W.G. Sanders. (2004). Upper Echelons Research Revisited: Antecedents, Elements, and Consequences of Top Management Team Composition. Journal of Management 30: 749-778.

Crossland, G. and D.C. Hambrick. (2007). How National Systems Differ in Their Constraints on Corporate Executives: A Study of CEO Effects in Three Countries. Strategic Management Journal 28 (8): 767-789.

Crossland, G. and D.C. Hambrick. (2011). Differences in Managerial Discretion Across Countries: How Nation Level Institutions Affect the Degree to Which CEOs Matter. Strategic Management Journal 32 (8): 797-819.

Estevez-Abe, M., Iversen, T. and Soskice, D. (2001). Social Protection and the Formation of Skills: a Reinterpretation of the Welfare State. In Varieties of Capitalism: The Institutional Foundations of Comparative Advantage, Hall P., Soskice, D. Oxford University Press: New York; 145-183.

Finkelstein, S. and R. D'Aveni, R. (1994). CEO duality as a double-edged sword: How boards of directors balance entrenchment avoidance and unity of command. Academy of Management Journal 37: 1079-1108.

Finkelstein, S., and Hambrick, D.C. (1996). Strategic Leadership: Top Executives and Their Effects on Organizations. St. Paul, MN: West.

Finkelstein, S., D.C. Hambrick, D.C. and A.A. Cannella. Jr. (2009). Strategic Leadership: Theory and Research on Executives, Top Management Teams, and Boards. Oxford: Oxford University Press.

Fiss, P.C. (2007). A Set-Theoretic Approach to Organizational Configurations. Academy of Management Review 32 (4): 1180-1198.

Greckhamer, T. (2016). CEO Compensation in Relation to Worker Compensation Across Countries: the Configurational Impact of Country-Level Institutions. Strategic Management Journal 37: 793-815.

Hambrick, D.C. (2007). Upper Echelon Theory: An Update. Academy of Management Review 32 (2): 334-343.

Hambrick, D.C. and S. Finkelstein. (1987). Managerial discretion: a bridge between polar views of organizational outcomes. In Research in Organizational Behavior, Staw B., Cummings LL (eds). JAI Press: Greenwich, CT; 369-406.

Hambrick, D.C., S.E. Humphrey and A. Gupta. (2015). Structural Interdependence Within Top Management Teams: a Key Moderator of Upper Echelons Predictions. Strategic Management Journal 36: 449-461.

Hambrick, D.C. and P.A. Mason. (1984). Upper Echelons: The Organisation as a Reflection of its Top Managers. Academy of Management Review 9 (2): 193-206.

Hill, C.W.L. and P. Phan. (1991). CEO tenure as a determinant of CEO pay. Academy of Management Journal 34: 707-717.

Hofstede G. (2001). Culture's Consequences: Comparing Values, Behaviors, Institutions, and Organizations across Nations (2nd edn). Sage: Thousand Oaks, CA.

La Porta, R., F. Lopez-de-Silanes and A. Shleifer. (1999). Corporate Ownership Around the World. Journal of Finance 54: 471-517. 
La Porta, R., F. Lopez-de-Silanes, A. Shleifer and R. Vishny. 1997. Legal determinants of external finance. Journal of Finance 52: 1131-1150.

Lambert R.A, D.F. Larcker and K. Weigelt, (1993). The Structure of Organizational Incentives. Administrative Science Quarterly 38(3): 438-461.

Leischnig, A., S.C. Henneberg and S.C. Thornton. (2014). Performing Configurational Analyses in Management Research: A Fuzzy Set Approach. Competitive paper submitted to the 30th IMP Conference 2014, Bordeaux.

Mahoney, J., \& Goertz, G. (2006). A tale of two cultures: Contrasting quantitative and qualitative research. Political analysis, 14(3), 227-249.

Olie, R., van Iterson, A. and Simsek, Z. (2012). When do CEOs Versus Top Management Teams Matter in Explaining Strategic Decision-Making Processes? International Studies of Management \& Organization 42 (2): 86-105.

Peng, M. W., \& Jiang, Y. (2010). Institutions behind family ownership and control in large firms. Journal of management Studies, 47(2), 253-273.

Schwartz, S. H. (1994). Are there universal aspects in the structure and contents of human values?. Journal of social issues, 50(4), 19-45.

Wade, J.B., C.A. Reilly III and T.G. Pollock. (2006). Overpaid CEOs and Underpaid Managers: Fairness and Executive Compensation. Organization Science 17: 527-540.

Zajac, E.J. and J.D. Westphal. (1996). Who Shall Succeed? How CEO/Board Preferences and Power Affect the Choice of New CEOs. The Academy of Management Journal 39 (1): 64-90. 